\title{
Nanostructured Multifilamentary Carbon-Copper Composites: Fabrication, Microstructural Characterization, and Properties
}

\author{
Evarice Yama Nzoma, Alain Guillet, and Philippe Pareige \\ Groupe de Physique des Matériaux, Université et INSA de Rouen, Avenue de l'Université, 76801 Saint Etienne du Rouvray, France \\ Correspondence should be addressed to Alain Guillet, alain.guillet@insa-rouen.fr
}

Received 15 October 2011; Revised 25 December 2011; Accepted 30 January 2012

Academic Editor: Shafiul Chowdhury

Copyright () 2012 Evarice Yama Nzoma et al. This is an open access article distributed under the Creative Commons Attribution License, which permits unrestricted use, distribution, and reproduction in any medium, provided the original work is properly cited.

This work is part of research on the emerging techniques to produce bulk nanostructured composites materials by severe plastic deformation and their characterization. Based on the Levi work, we present a new method to synthesize a composite wirecontaining carbon-nanosized filaments (graphite and $\mathrm{C}_{60}$ fullerenes) embedded in a copper matrix. The originality of this process is using powder media as fiber. Microstructures and electrical, mechanical, and thermal properties are presented.

\section{Introduction}

Plastic deformation processing is a "top-down" approach to nanostructuring metals and alloys based on the accumulation of ultralarge plastic strain to achieve microstructure refinement [1]. Various plastic-deformation techniques have been developed to produce nanostructured materials over the last two decades $[2,3]$. The more common techniques are Equal-Channel Angular Pressing (ECAP) [4], High-Pressure Torsion (HPT) [5, 6], and Accumulative Roll Bonding (ARB) $[7,8]$. However, several variants and combination [9] of plastic deformation techniques, including accumulative repetitive deformation [3], were also developed Accumulative Spin-Bonding (ASB) [10], Equal Channel Angular Rolling (ECAR) [11, 12], Cyclic Extrusion Compression (CEC) [13], Cyclic Closed-Die Forging (CCDF) [14, 15], Linear Flow Splitting (LFS) [16], Severe Torsion Straining (STS) [17], Torsion Extrusion Process (TEP) [18], Cylinder Covered Compression (CCC) [19], Asymmetric Rolling (AR) $[20,21]$, and Accumulative Deep Wire-Drawing and bonding (WD) [22-24]. In this paper, we present a modified wire-drawing process.

Wire drawing is an ancient manufacturing technique of metallic profiles, bars, rods, and wires. The best known example is cold drawing of eutectoid carbon steels ( $0.77 \mathrm{wt} \%$
C): plastic deformation close to $\varepsilon=4$ leads to a considerable refinement of the pearlitic microstructure down to the nanoscale [25-27]. Codrawing and coextrusion have also enabled the rise of a new class of nanostructured metal matrix composite materials whose industrial development is not mature but got intensive research. The fabrication process is based on the Levi's technique [28]. It consists of a series of steps involving first co-drawing of bimetallic monofilamentary macrocomposite, bundling and restacking of the drawn elements followed by another drawing operation. Accumulative drawing and re-stacking result in to multifilamentary materials with a priori incompatible properties, such a high yield strength and good electrical conductivity $[29,30]$. The archetypes of these materials are the $\mathrm{Cu}-\mathrm{Nb}$ micro- or nanocomposites, used to manufacture coils generating very high magnetic fields $[31,32]$. In these systems, the mechanical strength of composite in the plastic domain exceeds the "linear rule of mixtures". Except $\mathrm{Cu}-\mathrm{Nb}$, other bimetallic couples such as $\mathrm{Cu}-\mathrm{Fe}$ [28, 33, 34], $\mathrm{Cu}-\mathrm{Ag}$ $[35,36], \mathrm{Cu}-\mathrm{Cr}[37]$, and $\mathrm{Cu}-\mathrm{Ta}[38,39]$ are also studied. In $\mathrm{Cu}$-X couples, $\mathrm{X}$-fibers are used as reinforcement phase, and conducting phase is assumed by the copper matrix. The choice of the couple $\mathrm{Cu}-\mathrm{X}$ is generally dictated partly by a weak mutual solubility of $\mathrm{Cu}$ and $\mathrm{X}$ to reduce phase interactions but also by the reinforcing capacity of the $\mathrm{X}$ element. 
Under these conditions, the copper-carbon $(\mathrm{Cu}-\mathrm{C})$ pair is interesting to study. Indeed these two elements are extremely immiscible [40], and therefore the composite could combine the high electrical conductivity of copper with the interesting characteristics of carbon, namely, a low coefficient of thermal expansion (CTE) and good tribological properties [41, 42].

These alloys are used in various applications such as electrical contact materials with friction $[44,45]$ and as heat sink for electronic components which require a material with a low CTE. Their use is also proposed to replace silver in electronic circuits [46] and as materials to confine plasma in nuclear fusion reactors $[47,48]$.

However, manufacturing these composites is difficult because the mutual solubility of carbon and copper [49] and the wettability of carbon by liquid copper $[48,49]$ are extremely low. The main manufacturing processes are the infiltration of a network of carbon fibers or graphite with copper, the deposition of copper on carbon fibers by hollow cathode and powder metallurgy. Furthermore, to our best knowledge, no process is available to manufacture nanostructured copper-carbon multifilamentary wire.

Therefore, the objective of this research is to obtain copper matrix composite wires containing millions of nanoscaled carbon filaments. We have already demonstrated the ability to make such multifilamentary composite using the Levi's technique [50]. The originality of this process $[50,51]$ is that carbon powder is used as a fiber unlike most of multifilament composites which are made from two bulk metallic materials. The microstructures obtained were studied at different scales and we present and discuss the resulting electrical, mechanical, and thermal properties.

\section{Materials and Experimental Techniques}

\subsection{Materials}

2.1.1. Copper. Copper tubes used in processing route are $\mathrm{Cu}-$ b2 engineering materials with $99.95 \mathrm{wt} \%$ purity (deoxidized low phosphorous grade). We employed tubes of different diameters: tubes $\mathrm{A}\left(\varnothing_{\text {in. }}=4 \mathrm{~mm} / \emptyset_{\text {out. }}=8 \mathrm{~mm}\right)$ and tubes $\mathrm{B}\left(\varnothing_{\text {in. }}=10 \mathrm{~mm} / \varnothing_{\text {out. }}=12 \mathrm{~mm}\right)$. In order to recrystallize the microstructure, they were heat-treated at $500^{\circ} \mathrm{C}$ during 3 hours under medium vacuum, followed by pickling with diluted nitric acid solution to remove oxide layers.

2.1.2. Carbon. Two allotropes of carbon powders were used: natural graphite and $\mathrm{C}_{60}$ fullerenes. Graphite consists of agglomerated particles whose average size is $2 \mu \mathrm{m}[43,50]$. $\mathrm{C}_{60}$ fullerenes powder has a purity of $98 \mathrm{wt} \%$. SEM observation of $\mathrm{C}_{60}$ powder reveals agglomerates of equiaxed grains with a size ranging from tens to hundreds micrometers and faceted rods structure whose width is between 1 and $10 \mu \mathrm{m}$ and length is about $10 \mu \mathrm{m}[43,52,53]$. We assume that the equiaxed grains of $\mathrm{C}_{60}$ result from the fragmentation of rods [54]. Before any use, and to remove organic impurities from powder purification process, 3-hour heat treatment at $150^{\circ} \mathrm{C}$ under medium vacuum is applied [55]. X-ray analysis reveals that it does not change the structure of the truncated icosahedron $\mathrm{C}_{60}$ molecules and FCC solid structure [56-59].
2.2. Fabrication Technique. The first step (i.e., stage 0, monofilamentary composite) was synthesized by filling tube A with graphite or $\mathrm{C}_{60}$ fullerenes powders. The powder is manually compacted with a copper rod so it is uniformly distributed in the tube. The carbon-filled tube is then drawn up to $0.7 \mathrm{~mm}$ diameter. It is thereupon cut into pieces of same length which are bundled and introduced into tube B. The assembly is drawn again up to $0.7 \mathrm{~mm}$ diameter (stage 1) as shown schematically in Figure 1. A recrystallization heat treatment $\left(500^{\circ} \mathrm{C}, 3 \mathrm{~h}\right.$, under medium vacuum) is applied at the end of each stage or when fractures occur during the drawing operations.

The evolution of graphite and $\mathrm{C}_{60}$ fullerenes fibers number embedded in the copper matrix according to re-stacking stages is given in Table 1 . At the end of the processing $\mathrm{Cu}-\mathrm{C}_{\mathrm{Gr}}$ (final diameter: $0.8 \mathrm{~mm}$ with about $3.1 \times 10^{7}$ filaments of graphite and $\mathrm{Cu}-\mathrm{C}_{60}$ wires (final diameter: $3 \mathrm{~mm}$ with about $1.33 \times 10^{6}$ filaments of $\mathrm{C}_{60}$ ) are obtained.

2.3. Microstructural Observations and Mechanical, Electrical, and Thermal Characterizations Techniques. The samples microstructures were characterized by optical microscopy (OM) and scanning electron microscopy (SEM) following a metallographic preparation: mounting in a bakelite resin, mechanical polishing ending with $3 \mu \mathrm{m}$ diamond paste and chemical-mechanical polishing with a colloidal suspension of silica to which few drops of hydrogen peroxide were added. The microstructure of the copper matrix is revealed by etching few seconds with an iron chloride alcoholic solution. The OM observations were made with an Olympus microscope coupled to a CCD camera to acquire digital images enabling image analysis (AnalySIS software from the Olympus Soft Imaging System Company). The SEM images were obtained from a LEO FE1530 equipped with a field emission gun.

The deformation and recrystallized texture in metals with FCC lattices have been studied for a long time $[60,61]$. The main method to study crystallographic orientation is Xray diffraction texture analysis. The texture measurements were performed using X-ray four-circle diffractometer. The samples have coin-like shape between $4 \mathrm{~mm}$ to $5 \mathrm{~mm}$ in diameter and a thickness of less than $6 \mathrm{~mm}$. One side is polished to equalize the height of the carbon and copper. Then the samples were etched to remove the hardening owed by polishing operations. Due to small carbon filaments cross-section, we have obtained only copper texture measurements. The signal from the carbon was too weak to produce satisfactory pattern. The acquisition has required from 10 to 20 hours counting time.

The mechanical tests were carried out at the initial strain rates of $\dot{\varepsilon}=3.3 \cdot 10^{-4} \mathrm{~s}^{-1}$ (cross-head speed of $2 \mathrm{~mm} / \mathrm{mm}$ ) at room temperature with an Instron 4483 tensile testing machine with a $2 \mathrm{kN}$ load cell. Samples for tensile have been annealed 3 hours at $500^{\circ} \mathrm{C}$, to obtain the same thermomechanical state to compare each stage. To measure electrical resistance, we used the four probes method using an OM21 microhmmeter from AOIP Company on annealed samples (3h @ $500^{\circ} \mathrm{C}$ ), to improve electrical conductivity. The resolution is $0.1 \mu \Omega$ and the accuracy is about $0.03 \%$. 


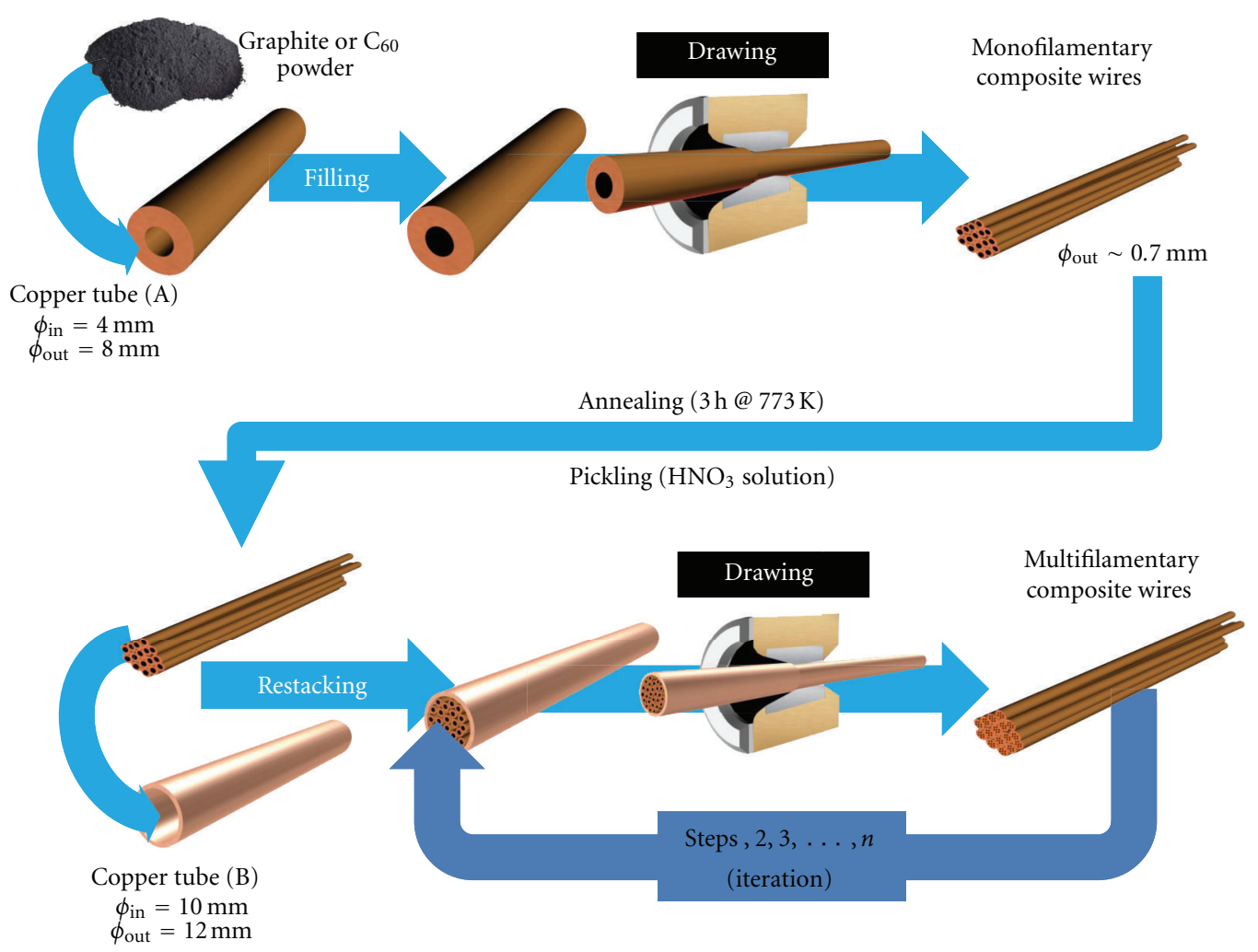

FIgURE 1: Schematic of Cu-C composites processing steps [43].

TABLE 1: Change in $\mathrm{Cu}-\mathrm{C}_{\mathrm{Gr}}$ and $\mathrm{Cu}-\mathrm{C}_{60}$ fibers number according to stage level.

\begin{tabular}{lll}
\hline Stage $(n)$ & $\mathrm{Cu}-\mathrm{C}_{\mathrm{Gr}}$ & $\mathrm{Cu}-\mathrm{C}_{60}$ \\
\hline 0 & 1 filament & 1 filament \\
1 & 110 filaments & 110 filaments \\
2 & 8800 filaments $(110 \times 80)$ & 12100 filaments $(110 \times 110)$ \\
3 & 704000 filaments $(8800 \times 80)$ & 1.33 million of filaments $(110 \times 12100)$ \\
4 & 31.7 million of filaments $(704000 \times 45)$ & - \\
\hline
\end{tabular}

The coefficient of linear thermal expansion of several composites was measured between 25 and $800^{\circ} \mathrm{C}$ with a differential dilatometer NETZSCH DIL 402C. The experimental conditions are as follows:

(i) heating rate: $300^{\circ} \mathrm{C} / \mathrm{h}$;

(ii) atmosphere: argon at 0.3 bar;

(iii) specimen dimensions: $\varnothing=4 \mathrm{~mm}, L=20 \mathrm{~mm}$;

(iv) number of test: 3 per measure;

(v) measurement uncertainty: $\pm 5 \%$.

\section{Microstructures}

Figure 2 presents $\mathrm{Cu}-\mathrm{C}_{\mathrm{Gr}}$ sample micrographs from "stage 1" for different strains. The interstices between "stage 0" wires are still visible, but they disappear gradually with increasing strain. Figure 3 shows the multiscale features characteristic of these materials.
This process therefore allows a considerable refinement of carbon filaments diameter. Indeed, starting from an initial $4 \mathrm{~mm}$ fiber diameter and after several stages of restacking, transverse filaments dimensions became nanoscale $200 \mathrm{~nm}$ and $350 \mathrm{~nm}$ for $\mathrm{Cu}-\mathrm{C}_{\mathrm{Gr}}$ and $\mathrm{Cu}-\mathrm{C}_{60}$, respectively. However, the morphological evolution of both $\mathrm{Cu}-\mathrm{C}_{\mathrm{Gr}}$ and $\mathrm{Cu}-\mathrm{C}_{60}$ composites is different, especially at the highest stages. For the $\mathrm{Cu}-\mathrm{C}_{\mathrm{Gr}}$ composite, three structures of graphite filaments are observed as shown in Figure 4.

The first graphite structure results from the agglomeration of several filaments which form large particles of several microns in diameter. The second structure consists of a network of very fine filaments of a few hundred nanometers thickness. This structure is reminiscent of the phenomenon of "curling" observed during the codeformation of bimetallic composite with different crystal structure and Young's modulus [62] (Figure 4(b)). The third category is represented by filaments whose cross-section is almost circular with a diameter of several tens of nanometers. 


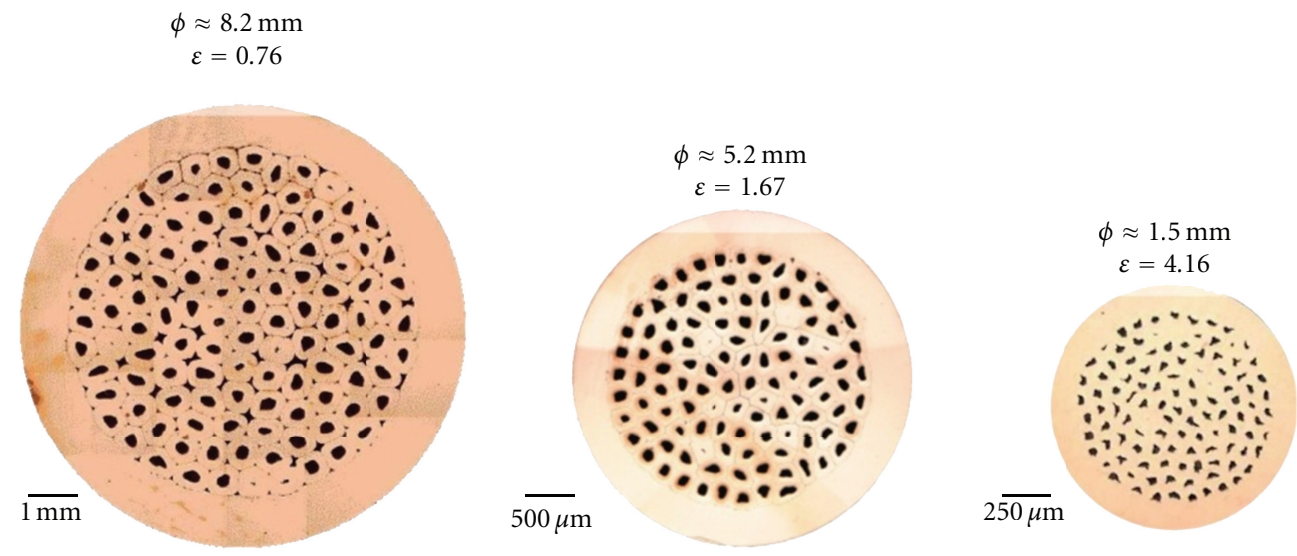

Figure 2: Optical micrographs of the $\mathrm{Cu}-\mathrm{C}_{\mathrm{Gr}}$ composite cross-sections at "stage 1" at different strains [43].

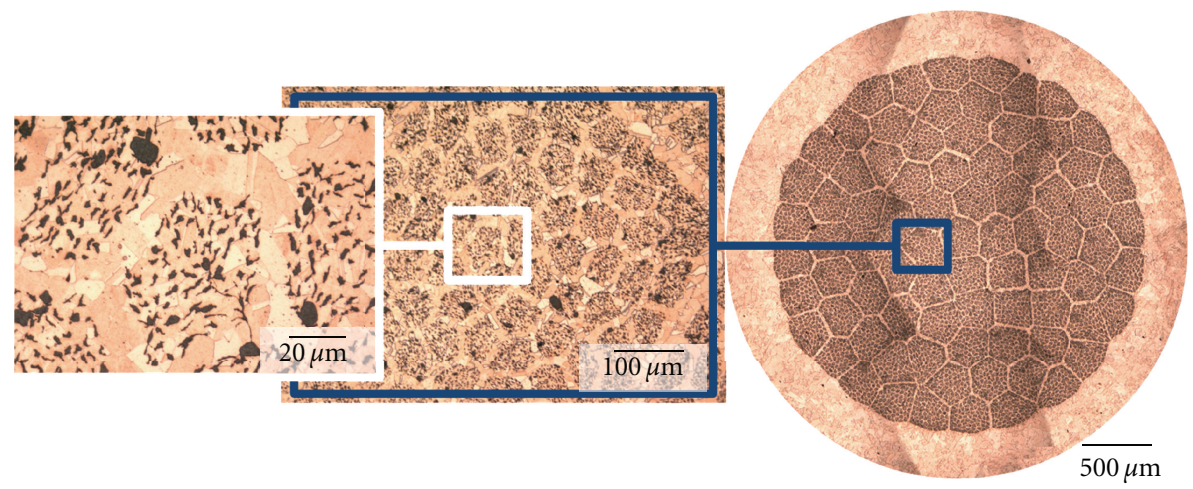

FIGURE 3: Optical cross-section micrographs of $\mathrm{Cu}-\mathrm{C}_{\mathrm{Gr}}$ composite at "stage 3", highlighting the multiscale structure (704 000 filaments) [43].

For $\mathrm{Cu}-\mathrm{C}_{60}$ composites, filaments are individually identifiable; however, unlike $\mathrm{Cu}-\mathrm{C}_{\mathrm{Gr}}$, no agglomeration occurs, though that $\mathrm{C}_{60}$ filaments do not have a circular cross-section but rather an elliptical or curvilinear.

The filaments diameter is also submicrometric. The difference between both composites morphology is directly connected to the crystalline structure and therefore mechanical behavior of each carbon phase. Indeed, $\mathrm{C}_{60}$ is a molecular solid (truncated icosahedron molecules) crystallizing in FCC structure and the intermolecular bonds are only Van der Waals type, hence sliding is easy. The graphite structure is hexagonal with $\sigma$ bonds between the carbon atoms of the hexagonal graphene planes and $\pi$ bonds between planes. Although sliding of graphene sheets with respect to another is possible, this cannot occur through the plane because the $\sigma$ bonds are very strong. The molecular solid $\mathrm{C}_{60}$ therefore allows a priori an easier accommodation of mechanical stress than graphite.

In addition, etching of the composite $\mathrm{Cu}-\mathrm{C}_{60}$ with an iron chloride solution highlights $\mathrm{C}_{60}$ filaments. Indeed, after dissolution of the copper matrix, we can observe naked filaments in "bundle-like" form (Figure 5(a)). These filaments are individually identifiable and keep their longitudinal appearance (Figure 5(b)).

This was also attempted on the $\mathrm{Cu}-\mathrm{C}_{\mathrm{Gr}}$ composite but without success; during the dissolution of the copper matrix,
TABLE 2: Mean grain size of copper matrix depending on the location of grains $\left(\mathrm{Cu}-\mathrm{C}_{60}\right.$ and $\mathrm{Cu}-\mathrm{C}_{\mathrm{Gr}}$. composites, stage $3, \varnothing=$ $5.2 \mathrm{~mm}$ ).

\begin{tabular}{lcc}
\hline Location of grain & \multicolumn{2}{c}{ Average grain size of copper $(\mu \mathrm{m})$} \\
$\mathrm{Cu}-\mathrm{C}_{60}$ stage 3 & $19 \pm 6$ & $19 \pm 6$ \\
Cu-C & Grage 3 \\
\hline Area 3 & $19 \pm 5$ & $19 \pm 5$ \\
Area 2 1 & $19 \pm 5 \pm 2$ & $8.4 \pm 2$ \\
Area 0 & $2.4 \pm 0.5$ & $5.0 \pm 1.8$ \\
\hline
\end{tabular}

and contrary to those of fullerenes, graphite does not retain a filamentary structure; it disperses into the etching solution. This reveals a loss of mechanical strength compared to $\mathrm{C}_{60}$ fullerenes filaments.

Composite materials were heated to a temperature where recrystallization can occur $\left(3 \mathrm{~h} @ 500^{\circ} \mathrm{C}\right)$, thereby strongly decreasing the number of defects caused by plastic deformation. However, as can be noted in Figure 6, the grain size of copper is not homogeneous.

Indeed, depending on the processing, it varies very significantly as shown in Table 2 . Grain growth is inhibited by the carbon filaments and the interfaces between the copper tubes [43]. 


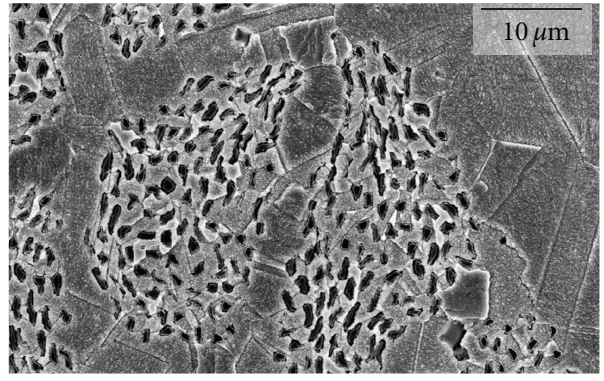

(a)

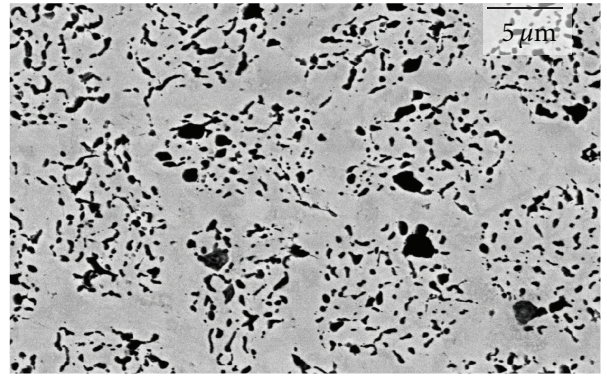

(b)

FIGURE 4: SEM micrographs to compare $\mathrm{Cu}-\mathrm{C}_{60}$ at stage 3 (a) and $\mathrm{Cu}-\mathrm{C}_{\mathrm{Gr}}$ at stage 4 (b) cross-section microstructure [43].

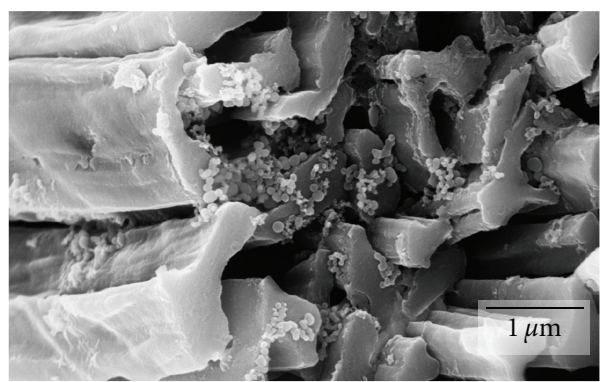

(a)

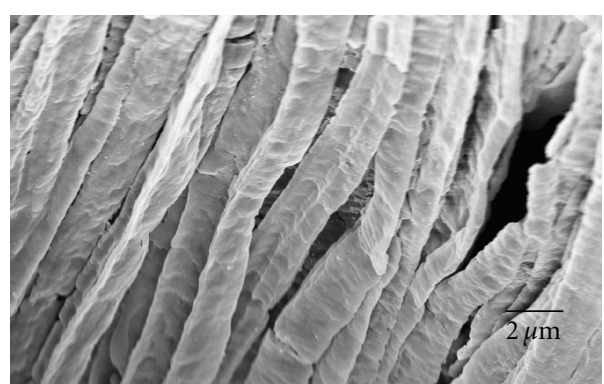

(b)

FIGURE 5: SEM images of etched $\mathrm{Cu}-\mathrm{C}_{60}$ composite. The submicrometer thickness and continuity of $\mathrm{C}_{60}$ filaments are underlined. Although they are in "bundle-like" form, they are, however, individually identifiable.

Microstructure study was supplemented by X-ray diffraction analysis to extract pole figures presented in Figure 6. The literature shows that wire-drawn FCC metals such as copper have a double-directions texture $\langle 111\rangle$ and $\langle 200\rangle$ [63-66] along drawing axis. As it be seen in Figures 7(a) and $7(\mathrm{~b})$, the $\langle 111\rangle$ texture component dominates in cold drawn and annealed matrix of $\mathrm{Cu}-\mathrm{C}_{60}$ and $\mathrm{Cu}-\mathrm{C}_{\mathrm{Gr}}$ composites. However, the intensity varies from one composite to another and from one stage to another. The highest degree of texturing is observed in steps 1 and 3 for $\mathrm{Cu}-\mathrm{C}_{\mathrm{Gr}}$ composite materials and at step 1 for $\mathrm{Cu}-\mathrm{C}_{60}$ composite materials. The $\langle 100\rangle$ component comes in lower intensity except for the composite $\mathrm{Cu}-\mathrm{C}_{\mathrm{Gr}}$ in step 1 .

According to several studies [67-69] intermediate recrystallization annealing and severe deformation $(\varepsilon<9)$ may affect and change the crystallographic orientations of deformed copper matrix. On the one hand, they showed that copper, which has undergone a deformation of $\varepsilon<9$, develops a $\langle 111\rangle$ structural component in majority and more stable $[70,71]$. On the other hand, intermediate recrystallization annealing and the application of very high deformations causing dynamic recrystallization of the $\mathrm{Cu}$ matrix [72] will promote the development of $\langle 100\rangle$ component. The presence of these two types of texture in our samples shows that there has been deformation and then recrystallization of the copper matrix, although textures associated with intermediate annealed composites are low except for the composite $\mathrm{Cu}-\mathrm{C}_{\mathrm{Gr}}$ stage 1 . We see globally on both types of composite that an increase of the number of stages $\left(\mathrm{Cu}-\mathrm{C}_{60}\right.$ step 2 and $\mathrm{Cu}-\mathrm{C}_{\mathrm{Gr}}$ stage 4) causes a decrease of the intensity of the $\langle 111\rangle$ texture component. Indeed, Dubois et al. [73] show that this regime is specific to nanocomposites metal and corresponds to a frustration of the normal recovery and recrystallization processes, impeded by the increased thermal resistance of $\mathrm{Cu}$ nanochannels.

\section{Results and Discussion}

4.1. Electrical Resistivity. $\mathrm{Cu}-\mathrm{C}_{\mathrm{Gr}}$ and $\mathrm{Cu}-\mathrm{C}_{60}$ composites electrical resistivity is around $2 \mu \Omega \cdot \mathrm{cm}$, close to $\mathrm{Cu}-\mathrm{b} 2 \mathrm{cop}-$ per used for processing (Table 3 ). The presence of graphite or $\mathrm{C}_{60}$ fullerenes, the first being a poor conductor compared to copper, the second being an insulator [43], weakly influences the electrical conductivity of the composite. Electrical resistivities of both composite materials, $\mathrm{Cu}-\mathrm{C}_{\mathrm{Gr}}$ stage 4 (89\% IACS) and $\mathrm{Cu}-\mathrm{C}_{60}$ stage 3 (85\% IACS), are lower than most metals and copper alloys. Only silver (106\% IACS) and pure copper (101\% IACS) have the lowest electrical conductivity.

4.2. Mechanical Properties. The stress-strain curves of $\mathrm{Cu}-$ $\mathrm{C}_{60}$ and $\mathrm{Cu}-\mathrm{C}_{\mathrm{Gr}}$ are given in Figures $8(\mathrm{a})$ and $8(\mathrm{~b})$, respectively. The tests were performed on materials annealed at $500^{\circ} \mathrm{C}$ during 3 hours. We deliberately choose to compare the materials properties after a recrystallization annealing, because the resistivity decreases, and because in the deformed state the material is often fragile. Furthermore, comparing the mechanical properties of the as-fabricated 

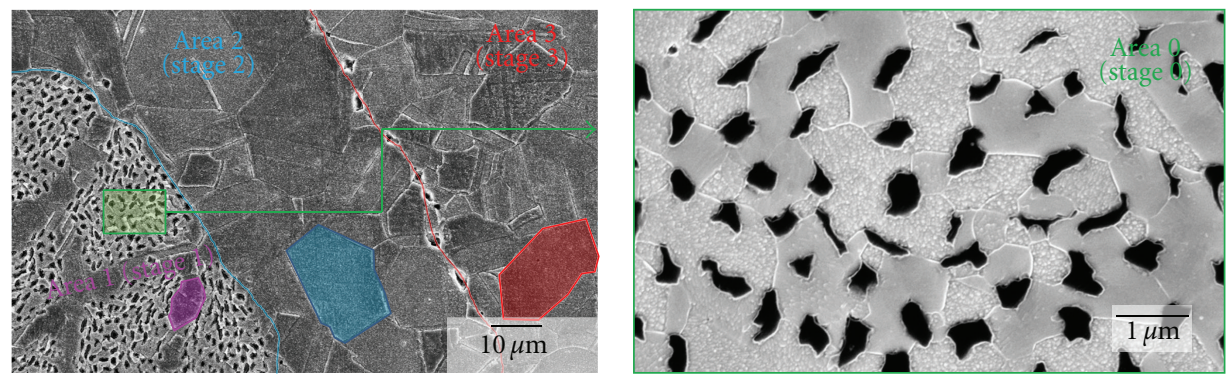

Figure 6: SEM micrographs highlighting copper matrix grains $\left(\mathrm{Cu}-\mathrm{C}_{60}\right.$, stage $\left.3 \varnothing=5.2 \mathrm{~mm}\right)$ [43] .
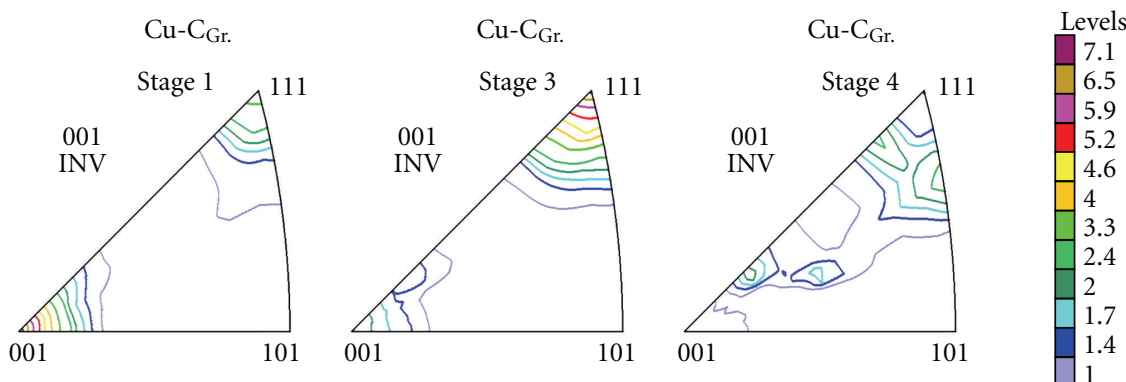

$\operatorname{Min}=0.026$ $2007 / 01 / 25$

(a)
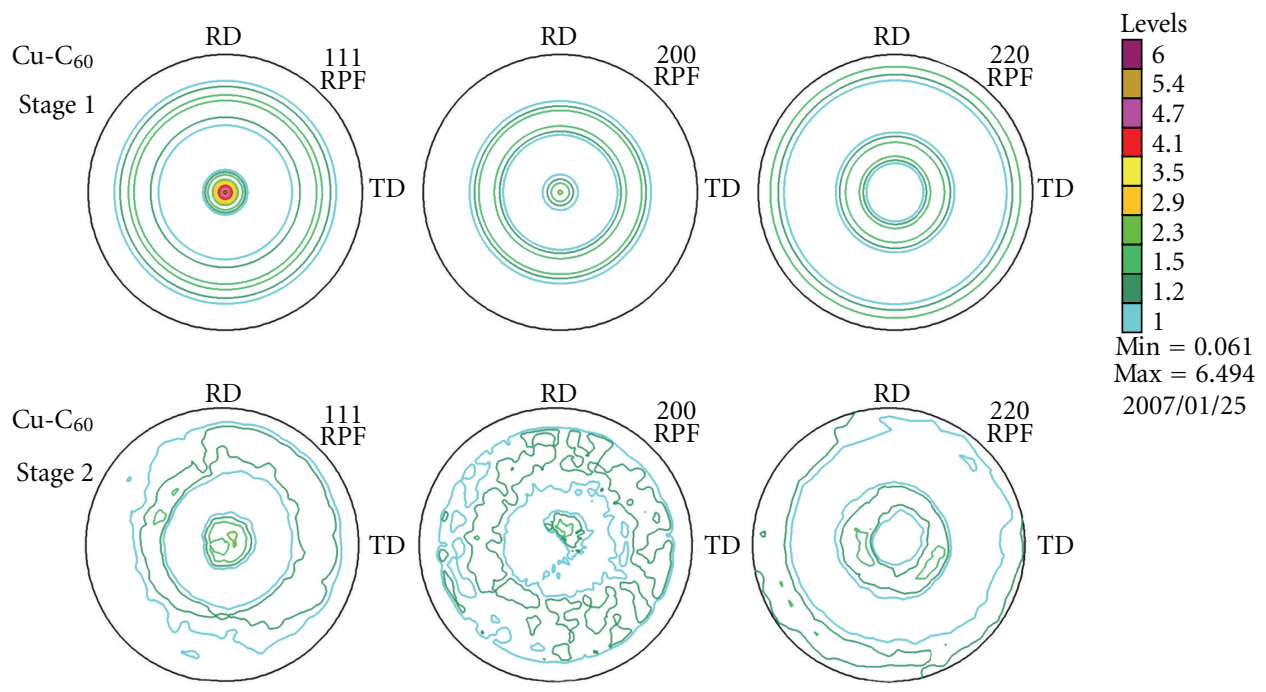

2007/01/25

(b)

FIGURE 7: X-ray pole figures of Cu matrix after deformation and recrystallization showing $\langle 111\rangle$ and $\langle 100\rangle$ texture components measured from cross-section of rod sample. (a) Pole figures of samples $\mathrm{Cu}-\mathrm{C}_{\mathrm{Gr}}$ in stages 1,3 , and 4 . (b) $\mathrm{Cu}-\mathrm{C}_{60}$ in stages 1 and 2 pole figures. All samples were annealed 3 hours at $500^{\circ} \mathrm{C}[43]$.

TABle 3: Electrical resistivities (conductivities) of $\mathrm{Cu}-\mathrm{C}_{60}$ and $\mathrm{Cu}-\mathrm{C}_{\mathrm{Gr}}$ composites and $\mathrm{Cu}$ after recristallization heat treatment $\left(500^{\circ} \mathrm{C}, 3 \mathrm{~h}\right.$ ).

\begin{tabular}{lccc}
\hline & $\mathrm{Cu}$ & $\mathrm{Cu}-\mathrm{C}_{\mathrm{Gr}}($ stage 4) & $\mathrm{Cu}-\mathrm{C}_{60}($ stage 3) \\
\hline Surface fraction $f_{\mathrm{S}}$ & - & 0.061 & $0.096 \pm 0.006$ \\
Nb. filaments $\left(\times 10^{6}\right)$ & - & 31.7 & 1.33 \\
$\rho(\mu \Omega \cdot \mathrm{cm})(\% \mathrm{IACS})$ & $1.87 \pm 0.06(92.2 \pm 3.0)$ & $1.94 \pm 0.15(88.9 \pm 6.9)$ & $2.03 \pm 0.05(84.9 \pm 2.1)$ \\
\hline
\end{tabular}




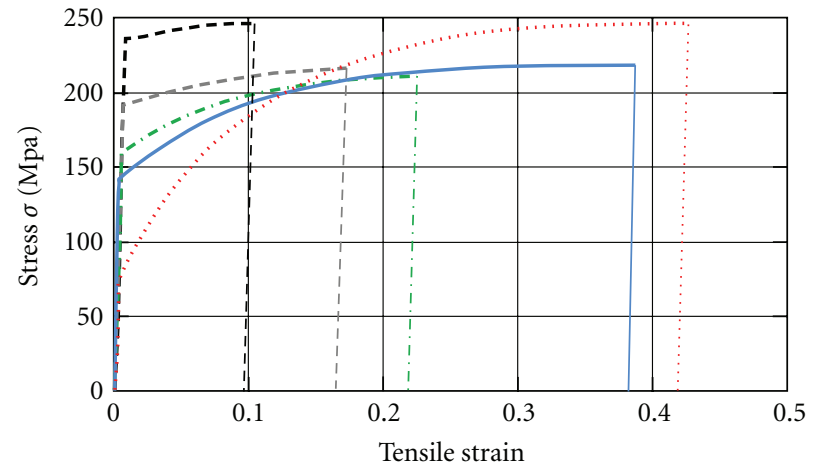

(a)

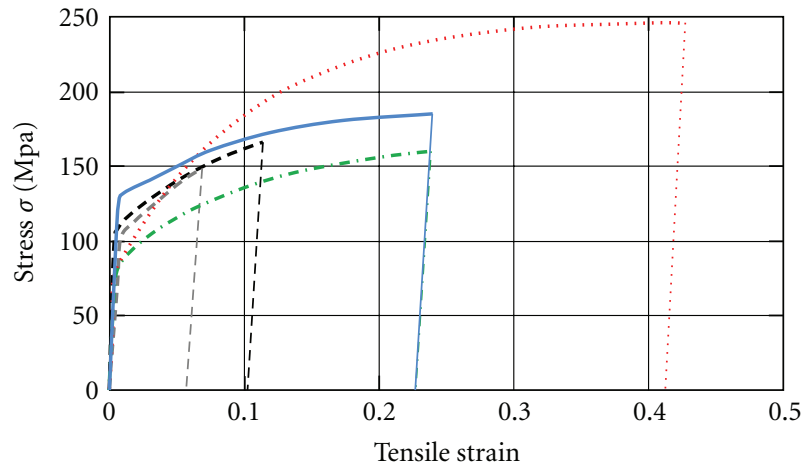

- $\mathrm{Cu}-\mathrm{C}_{60}$ stage 0
- - - $\mathrm{Cu}-\mathrm{C}_{60}$ stage 1
- - - $\mathrm{Cu}-\mathrm{C}_{60}$ stage 2

-- - $\mathrm{Cu}-\mathrm{C}_{60}$ stage 3

...... $\mathrm{Cu}$

(b)

Figure 8: Engineering stress-strain curve of (a) $\mathrm{Cu}-\mathrm{C}_{60}$ and (b) $\mathrm{Cu}-\mathrm{C}_{\mathrm{Gr}}$ composites from stages 0 to 3 and comparison with copper [43].

TABle 4: Mechanical properties of $\mathrm{Cu}-\mathrm{C}_{60}$ and $\mathrm{Cu}-\mathrm{C}_{\mathrm{Gr}}$ composites (stage 3) and comparison with copper.

\begin{tabular}{lccc}
\hline & Copper & $\mathrm{Cu} \mathrm{C}_{\mathrm{Gr}}$ stage 3 & $\mathrm{Cu}^{-\mathrm{C}_{60} \text { stage 3 }}$ \\
\hline Surface fraction $f_{S}$ & - & 0.095 & $0.096 \pm 0.006$ \\
Nb. of filaments & - & 704000 & 1.33 million \\
$R_{e 0.2 \%}(\mathrm{MPa})$ & $81 \pm 11$ & $110 \pm 3$ & $238 \pm 36$ \\
$A_{r}(\%)$ & $41 \pm 3$ & $10 \pm 4$ & $10 \pm 5$ \\
$R_{m}(\mathrm{MPa})$ & $248 \pm 11$ & $166 \pm 3$ & $248 \pm 26$ \\
\hline
\end{tabular}

composite would require a precise quantification of the plastic deformation for each stage, however, the deformation during processing is inhomogeneous. Indeed, following restacking, there is first plastic deformation of the outer tube and filling of gaps between the wires (Figure 2), and plastic deformation of these wires occurs. Therefore, since before restacking, wires are annealed, the outer tube containing them undergoes greater plastic deformation.

The stress-strain curves for the different re-stacking stages are shown in Figure 8. Compared to pure copper, the yield strength of $\mathrm{Cu}-\mathrm{C}_{60}$ composites increases significantly while the elongation decreases.

Meanwhile the stress/strain curves for $\mathrm{Cu}-\mathrm{C}_{\mathrm{Gr}}$ composites are always below the copper one in the plastic regime. We have no certain explanation for this behaviour. In the present state of our knowledge, the comparison with the hardening of "pure" copper is difficult because even if the process of forming and heat treatments are the same, the resulting microstructures are very different. The recrystallized microstructure of copper is obviously homogeneous in terms of grain size (30 to 40 microns) [43]. That of $\mathrm{Cu}-$ $\mathrm{C}_{\mathrm{Gr}}$ is biphasic and the grain size is heterogeneous as shown in Table 2: it varies between 2 and 19 microns, and regardless of the presence of graphite filaments, we ignore the work hardening behavior of such microstructure during tensile testing. Furthermore, the presence of an irregular and heterogeneous distribution of graphite filaments with increasing re-stacking does not allow yet a prediction of the mechanical behavior of the composites. This may explain why the stress/strain curves for $\mathrm{Cu}-\mathrm{C}_{\mathrm{Gr}}$ composites at stage 1,2 , and 3 are below the one at stage 0 .

The mechanical properties determined from these stressstrain curves are shown in Table 4 but only for stage 3 .

The presence of carbon filaments (graphite or $\mathrm{C}_{60}$ ) increases significantly the yield stress compared to pure copper, but decreases elongation at fracture. However, $\mathrm{Cu}-\mathrm{C}_{60}$ has the most remarkable increase since yield stress reached $(238 \pm$ 36) MPa compared to $(81 \pm 11) \mathrm{MPa}$ for copper. The variation of yield stress depends on the mean grain size (d); the strengthening results from grain refinement according to Hall-Petch relation [74-76]:

$$
\sigma(\varepsilon)=\sigma_{0}+k \cdot d^{-1 / 2},
$$

where $k$, which falls between 0.104 and $0.25 \mathrm{MPa} / \mathrm{mm}^{1 / 2}$ [72, 77-79], is the so-called Hall-Petch "constant," despite the fact that it is strain, temperature, and strain rate dependent. $\sigma_{0}$ is the intrinsic stress (36 MPa [79]). The Hall-Petch model is based on the hypothesis that grain boundaries act as obstacles in dislocation movements. That is to say, as the grain size is reduced, dislocation movements are impeded by grain boundaries, so the yield stress of specimen increases. We have made two assumptions. First, we consider that only copper matrix contributes to the strength because carbon (graphite, $\mathrm{C}_{60}$ ) filaments have a small mechanical strength compared to copper. Second, we introduced a modified HallPetch relation by taking into account the surface fraction of each area (see Figure 6) which has different mean grain size. Then the Hall-Petch equation becomes

$$
\sigma=\sigma_{0}+k \cdot \sum_{i=1}^{n} \frac{f_{s}^{i}}{\sqrt{d_{i}}},
$$

where $f_{s}^{i}$ is the fraction surface of grains with $d_{i}$ size.

After calculation, we obtain a yield in the range of 63$100 \mathrm{MPa}$ according on the values of $k$. However, this result, 
TABLE 5: Linear coefficient of thermal expansion of $\mathrm{Cu}-\mathrm{C}_{\mathrm{Gr}}$ and $\mathrm{Cu}-\mathrm{C}_{60}$ composites in the temperature range $\left(25^{\circ} \mathrm{C}-100^{\circ} \mathrm{C}\right)$ depending on the number of filaments and carbon fraction surface.

\begin{tabular}{|c|c|c|c|c|c|}
\hline & & Stage 1 & Stage 2 & Stage 3 & Stage 4 \\
\hline \multirow{3}{*}{$\mathrm{Cu}-\mathrm{C}_{\mathrm{Gr}}$} & $\mathrm{Nb}$ of filaments of $\mathrm{C}_{\mathrm{Gr}}$ & 110 & 8800 & 704000 & 31.7 million \\
\hline & Surface fraction of $\mathrm{C}_{\mathrm{Gr}}$ & 0.092 & 0.074 & 0.095 & 0.061 \\
\hline & $\mathrm{CTE}_{\mathrm{mes}}\left(\times 10^{-6 \circ} \mathrm{C}^{-1}\right)$ & 13.7 & 16.8 & 15.1 & 11 \\
\hline \multirow{3}{*}{$\mathrm{Cu}-\mathrm{C}_{60}$} & $\mathrm{Nb}$ of filaments of $\mathrm{C}_{60}$ & - & 12100 & 1.33 millions & - \\
\hline & Surface fraction of $\mathrm{C}_{60}$ & - & $0.11 \pm 0.05$ & $0.096 \pm 0.005$ & - \\
\hline & $\mathrm{CDT}_{\mathrm{mes}}\left(\times 10^{-6 \circ} \mathrm{C}^{-1}\right)$ & - & 12.4 & 13.3 & - \\
\hline
\end{tabular}

comparable to that of the $\mathrm{Cu}-\mathrm{C}_{\mathrm{Gr}}$ composite at stage 3 , is below that experimental value which is $110 \pm 3 \mathrm{MPa}$. In the case of $\mathrm{Cu}-\mathrm{C}_{60}$ composite, the values of the theoretical yield strengths range from $67 \mathrm{MPa}$ to $112 \mathrm{MPa}$ (with an average of $86 \pm 23 \mathrm{MPa}$ ). The experimental value is nearly three times greater than calculated one.

The application of this modified Hall-Petch relationship shows that grain refinement does not fully explain this increase [43].

Other contributions should be considered especially the influence of matrix texture. It was demonstrated that even a moderate texture can result in significant anisotropy in the plastic behavior of $\mathrm{Cu}$ matrix [80]. Also a beginning of polymerization of filaments $\mathrm{C}_{60}[81,82]$ and structure change can slightly contribute to mechanical reinforcement. A contribution from the $\mathrm{Cu}-\mathrm{C}$ interface is unlikely given the low solubility of carbon and the absence of copper-carbon compounds [40].

4.3. Thermal Properties. The average coefficient of thermal expansion between 25 and $100^{\circ} \mathrm{C}$ (CTE) of $\mathrm{Cu}-\mathrm{C}_{60}$ and $\mathrm{Cu}-$ $\mathrm{C}_{\mathrm{Gr}}$ composite is given in Table 5. With the exception of the composite $\mathrm{Cu}-\mathrm{C}_{\mathrm{Gr}}$ stage 2 , the presence of graphite or fullerenes decreases significantly CTE compared to the pure copper $\left(\mathrm{CTE}=17 \times 10^{-6 \circ} \mathrm{C}^{-1}\right)[83]$.

The decrease of CTE is the largest for $\mathrm{Cu}-\mathrm{C}_{\mathrm{Gr}}$ at stage $4,\left(11 \times 10^{-6 \circ} \mathrm{C}^{-1}\right)$. It is also surprising that the CTE of $\mathrm{Cu}-\mathrm{C}_{60}$ is well below the CTE of the components, namely, $17 \times 10^{-6 \circ} \mathrm{C}^{-1}$ for copper and $20 \times 10^{-6 \circ} \mathrm{C}^{-1}$ for $\mathrm{C}_{60}$. Therefore, we may assume that successive annealing and cumulate deformation can lead to a polymerization of $\mathrm{C}_{60}$ with a change of structure and properties [81, 82].

\section{Conclusions and Perspectives}

In this work we demonstrate that the manufacturing method of bimetallic composite multifilamentary wire by codrawing and re-stacking is applicable to the development of CopperCarbon micro- or nanocomposite wires where the matrix is the metallic phase and the second phase is a carbon powder. The fabrication process combines simultaneously plastic deformation and powder compaction. The successive wiredrawing and re-stacking lead to multi-scale microstructure of the metal matrix. The diameter of carbon filaments is greatly reduced. Thus, the $\mathrm{Cu}-\mathrm{C}_{\mathrm{Gr}}$ wire has more than $3.1 \times$ $10^{7}$ graphite filaments with a diameter of $200 \mathrm{~nm}$, while that of $\mathrm{Cu}-\mathrm{C}_{60}$ contains more than a million of filaments with $350 \mathrm{~nm}$ in diameter.

This process enables development of materials with properties better or close to copper. Indeed, the yield stress is significantly increased compared with that of copper, while the elongation decreases dramatically. The electrical conductivity is weakly influenced by the presence of carbon (graphite or fullerenes), but the coefficient of linear thermal expansion decreases notably.

Cumulative co-drawing and bundling can be extended to other metal-carbon systems like aluminum-carbon nanotubes and nonmetallic, such as metal-polymer [84]. We also demonstrated that after drawing and etching, this process enables to obtain naked $\mathrm{C}_{60}$ fullerenes filaments with nano size section. These filaments, thus highlighted, can be used as fibers which could be coated by metal, polymeric, or ceramic matrix.

\section{Acknowledgments}

This work is supported by the "Groupe de Physique des Matériaux" laboratory in Nanostructures and Phase Transformation Research Team. The authors are grateful to CRITT Metal 2T of Nancy for linear thermal expansion analysis and "Materials and Processes Sciences Laboratory" (LSMP) in Paris XIII University for the texture measurements.

\section{References}

[1] A. Misra and L. Thilly, "Structural metals at extremes," MRS Bulletin, vol. 35, no. 12, pp. 965-972, 2010.

[2] Y. Zhu, R. Z. Valiev, T. G. Langdon, N. Tsuji, and K. Lu, "Processing of nanostructured metals and alloys via plastic deformation," MRS Bulletin, vol. 35, no. 12, pp. 977-981, 2010.

[3] A. Azushima, R. Kopp, A. Korhonen et al., "Severe plastic deformation (SPD) processes for metals," CIRP Annals. Manufacturing Technology, vol. 57, no. 2, pp. 716-735, 2008.

[4] R. Z. Valiev and T. G. Langdon, "Principles of equal-channel angular pressing as a processing tool for grain refinement," Progress in Materials Science, vol. 51, no. 7, pp. 881-981, 2006.

[5] P. W. Bridgman, "Effects of high shearing stress combined with high hydrostatic pressure," Physical Review, vol. 48, no. 10, pp. 825-847, 1935.

[6] S. Erbel, "Mechanical properties and structure of extremely strain-hardened copper," Metals Technology, vol. 6, no. 12, pp. 482-486, 1979.

[7] N. Tsuji, Y. Saito, S. H. Lee, and Y. Minamino, "ARB (accumulative roll-bonding) and other new techniques to produce bulk 
ultrafine grained materials," Advanced Engineering Materials, vol. 5, no. 5, pp. 338-344, 2003.

[8] N. Tsuji, "Nature of deformation behavior in ultrafine grained metallic materials," in Proceedings of the 3rd International Conference on Nanomaterials by Severe Plastic Deformation (Nano SPD3 '05), Fukuoka, Japan, 2005.

[9] D.-F. Zhang, H.-J. HU, F. S. Pan, M.-B. Yang, and J.-P. Zhang, "Numerical and physical simulation of new SPD method combining extrusion and equal channel angular pressing for AZ31 magnesium alloy," Transactions of Nonferrous Metals Society of China, vol. 20, no. 3, pp. 478-483, 2010.

[10] M. S. Mohebbi and A. Akbarzadeh, "Accumulative spin-bonding (ASB) as a novel SPD process for fabrication of nanostructured tubes," Materials Science and Engineering A, vol. 528, no. 1, pp. 180-188, 2010.

[11] J. C. Lee, H. K. Seok, J. Y. Suh, J. H. Han, and Y. H. Chung, "Structural evolution of a strip-cast al alloy sheet processed by continuous equal-channel angular pressing," Metallurgical and Materials Transactions A, vol. 33, no. 3, pp. 665-673, 2002.

[12] J. C. Lee, J. Y. Suh, and J. P. Ahn, "Work-softening behavior of the ultrafine-grained $\mathrm{Al}$ alloy processed by high-strainrate, dissimilar-channel angular pressing," Metallurgical and Materials Transactions A, vol. 34, no. 3, pp. 625-632, 2003.

[13] A. Korbel, M. Richert, and J. Richert, "The effects of very high cumulative deformation onstructure and mechanical properties of aluminium," in Proceedings of the 2nd RISO International Symposium on Metallurgy and Material Science Roskilde, pp. 445-450, Roskilde, Denmark, 1981.

[14] A. K. Ghosh and W. Huang, Investigations and Applications of Severe Plastic Deformation, vol. 80 of NATO Science Series, T. C. Lowe and R. Z. Valiev, Eds., Kluwer Academic Publications, Boston, Mass, USA, 2000.

[15] R. Kuziak, W. Zalecki, M. Pietrzyk, and S. Wçglarczyk, "New possibilities of achieving ultrafine grained microstructure in metals and alloys employing MaxStrain technology," Bulk and Graded Nanometals, vol. 101-102, pp. 43-48, 2005.

[16] P. Groche, D. Vucic, and M. Jöckel, "Basics of linear flow splitting," Journal of Materials Processing Technology, vol. 183, no. 2-3, pp. 249-255, 2007.

[17] K. Nakamura, K. Neishi, K. Kaneko, M. Nakagaki, and Z. Horita, "Development of severe torsion straining process for rapid continuous grain refinement," Materials Transactions, vol. 45, no. 12, pp. 3338-3342, 2004.

[18] S. Mizunuma, "Large straining behavior and microstructure refinement of several metals by torsion extrusion process," Materials Science Forum, vol. 503-504, pp. 185-190, 2006.

[19] X. Zhao, T. F. Jing, Y. W. Gao, J. F. Zhou, and W. Wang, "A new SPD process for spheroidal cast iron," Materials Letters, vol. 58, no. 19, pp. 2335-2339, 2004.

[20] J. H. Jiang, Y. Ding, F. Q. Zuo, and A. D. Shan, "Mechanical properties and microstructures of ultrafine-grained pure aluminum by asymmetric rolling," Scripta Materialia, vol. 60, pp. 905-908, 2009.

[21] Y. H. Ji and J. J. Park, "Development of severe plastic deformation by various asymmetric rolling processes," Materials Science and Engineering A, vol. 499, no. 1-2, pp. 14-17, 2009.

[22] K. Hono, M. Ohnuma, M. Murayama, S. Nishida, A. Yoshie, and T. Takahashi, "Cementite decomposition in heavily drawn pearlite steel wire,” Scripta Materialia, vol. 44, no. 6, pp. 977983,2001

[23] K. Hanazaki, N. Shigeiri, and N. Tsuji, "Change in microstructures and mechanical properties during deep wire drawing of copper," Materials Science and Engineering A, vol. 527, no. 2122, pp. 5699-5707, 2010.
[24] N. Tsuji and K. Hanazaki, "Nanostructure formation during deep wire-drawing of copper," Materials Science Forum, vol. 654-656, pp. 1201-1204, 2010.

[25] P. Watté, J. Van Humbeeck, E. Aernoudt, and I. Lefever, "Strain ageing in heavily drawn eutectoid steel wires," Scripta Materialia, vol. 34, no. 1, pp. 89-95, 1996.

[26] A. V. Korznikov, Y. V. Ivanisenko, D. V. Laptionok, I. M. Safarov, V. P. Pilyugin, and R. Z. Valiev, "Influence of severe plastic deformation on structure and phase composition of carbon steel," Nanostructured Materials, vol. 4, no. 2, pp. 159167, 1994.

[27] J. Languillaume, G. Kapelski, and B. Baudelet, "Cementite dissolution in heavily cold drawn pearlitic steel wires," Acta Materialia, vol. 45, no. 3, pp. 1201-1212, 1997.

[28] F. P. Levi, "Permanent magnets obtained by drawing compacts of parallel iron wires," Journal of Applied Physics, vol. 31, no. 8, pp. 1469-1471, 1966.

[29] A. M. Russell, L. S. Chumbley, and Y. Tian, "Deformation processed metal-metal composites," Advanced Engineering Materials, vol. 2, no. 1-2, pp. 11-22, 2000.

[30] D. Raabe, F. Heringhaus, U. Hangen, and G. Gottstein, "Investigation of a Cu-20 mass $\% \mathrm{Nb}$ in situ composite part I: fabrication, microstructure and mechanical properties," Zeitschrift fuer Metallkunde, vol. 86, no. 6, pp. 405-415, 1995.

[31] L. Thilly, M. Véron, O. Ludwig, F. Lecouturier, J. P. Peyrade, and S. Askénazy, "High-strength materials: in-situ investigations of dislocation behaviour in $\mathrm{Cu}-\mathrm{Nb}$ multifilamentary nanostructured composites," Philosophical Magazine A, vol. 82, no. 5, pp. 925-942, 2002.

[32] L. Thilly, M. Véron, O. Ludwig, and F. Lecouturier, "Deformation mechanism in high strength $\mathrm{Cu} / \mathrm{Nb}$ nanocomposites," Materials Science and Engineering A, vol. 309-310, pp. 510$513,2001$.

[33] X. Sauvage, F. Wetscher, and P. Pareige, "Mechanical alloying of $\mathrm{Cu}$ and $\mathrm{Fe}$ induced by severe plastic deformation of a $\mathrm{Cu}-$ Fe composite," Acta Materialia, vol. 53, no. 7, pp. 2127-2135, 2005.

[34] Y. S. Go and W. A. Spitzig, "Strengthening in deformationprocessed Cu-20\% Fe composites," Journal of Materials Science, vol. 26, no. 1, pp. 163-171, 1991.

[35] D. W. Yao and L. Meng, "Effects of solute, temperature and strain on the electrical resistivity of $\mathrm{Cu}-\mathrm{Ag}$ filamentary composites," Physica B, vol. 403, no. 19-20, pp. 3384-3388, 2008.

[36] Y. Sakai and H. J. Schneider-Muntau, "Ultra-high strength, high conductivity Cu-Ag alloy wires," Acta Materialia, vol. 45, no. 3, pp. 1017-1023, 1997.

[37] C. Masuda and Y. Tanaka, "Fatigue properties of Cu-Cr in situ composite," International Journal of Fatigue, vol. 28, no. 10, pp. 1426-1434, 2006.

[38] K. Sakurai, Y. Yamada, C. H. Lee, T. Fukunaga, and U. Mizutani, "Solid state amorphization in the CuTa alloy system," Materials Science and Engineering A, vol. 134, no. C, pp. 1414-1417, 1991.

[39] L. Thilly, J. Colin, F. Lecouturier, J. P. Peyrade, J. Grilhé, and S. Askénazy, "Interface instability in the drawing process of copper/tantalum conductors," Acta Materialia, vol. 47, no. 3, pp. 853-857, 1999.

[40] T. B. Massalski and H. Okamoto, Binary Alloy Phase Diagrams, ASM International, Ohio, USA, 2nd edition, 1990.

[41] S. F. Moustafa, S. A. El-Badry, A. M. Sanad, and B. Kieback, "Friction and wear of copper-graphite composites made with $\mathrm{Cu}$-coated and uncoated graphite powders," Wear, vol. 253, no. 7-8, pp. 699-710, 2002. 
[42] T. Oku, A. Kurumada, T. Sogabe, T. Oku, T. Hiraoka, and K. Kuroda, "Effects of titanium impregnation on the thermal conductivity of carbon/copper composite materials," Journal of Nuclear Materials, vol. 257, no. 1, pp. 59-66, 1998.

[43] E. Y. Nzoma, Elaboration par déformation plastique intense et caractérisation de composites multifilamentaires nanostructurés cuivre-carbone, Ph.D. thesis, University of Rouen, France, 2009.

[44] J. M. García-Márquez, N. Antón, A. Jimenez, M. Madrid, M. A. Martinez, and J. A. Bas, "Viability study and mechanical characterisation of copper-graphite electrical contacts produced by adhesive joining," Journal of Materials Processing Technology, vol. 143-144, no. 1, pp. 290-293, 2003.

[45] D. H. He and R. Manory, "A novel electrical contact material with improved self-lubrication for railway current collectors," Wear, vol. 249, no. 7, pp. 626-636, 2001.

[46] S. Dorfman and D. Fuks, "Diffusivity of carbon in the copper matrix. Influence of alloying," Composites Part A, vol. 27, no. 9, pp. 697-701, 1996.

[47] C. H. Stoessel, J. C. Withers, C. Pan, D. Wallace, and R. O. Loutfy, "Improved hollow cathode magnetron deposition for producing high thermal conductivity graphite-copper composite," Surface and Coatings Technology, vol. 76-77, no. 2, pp. 640-644, 1995.

[48] P. Appendino, M. Ferraris, V. Casalegno, M. Salvo, M. Merola, and M. Grattarola, "Direct joining of CFC to copper," Journal of Nuclear Materials. B, vol. 329-333, no. 1-3, pp. 1563-1566, 2004.

[49] G. A. López and E. J. Mittemeijer, "The solubility of C in solid Cu," Scripta Materialia, vol. 51, no. 1, pp. 1-5, 2004.

[50] A. Guillet, E. Y. Nzoma, and P. Pareige, "A new processing technique for copper-graphite multifilamentary nanocomposite wire: microstructures and electrical properties," Journal of Materials Processing Technology, vol. 182, no. 1-3, pp. 50-57, 2007.

[51] P. Tautzenberger, L. Tillmann, H. Wilhelm, and D. Stoeckel, "Deformation and properties of fibre reinforced composite materials," Wire, vol. 28, no. 2, pp. 65-71, 1979.

[52] F. Michaud, M. Barrio, S. Toscani, V. Agafonov, H. Szwarc, and R. Céolin, "Solid-state studies on solvated [60] fullerene crystals grown from trichlorethylene," Fullerene Science and Technology, vol. 5, no. 7, pp. 1645-1650, 1997.

[53] R. Ceolin, "A fullerene or footballene $\left(C_{60}\right)$ is a molecule made up of 60 or 70 atoms of carbon located at the vertices of hexagons and pentagons to form a closed cage that looks similar to a football," CNRS-INFO (URA1104-Physical Chemistry of Raw Materials, ORSAY), vol. 233, 1991.

[54] G. Beaucage, J. E. Mark, G. T. Burns, and H. D.-Wu, Nanostructured Powders and Their Industrial Application, Proceedings of the Materials Research Society, Materials Research Society, San Francisco Calif, USA, 1998.

[55] E. E. B. Campbell, "Fullerene sources," in Fullerene Collision Reactions, Developments in Fullerene Science, 1st edition, 2004.

[56] W. Kratschmer, L. D. Lamb, K. Fostiropoulos, and D. R. Huffman, "Solid $\mathrm{C}_{60}$ : a new form of carbon," Nature, vol. 347, no. 6291, pp. 354-358, 1990.

[57] J. L. Wragg, J. E. Chamberlain, H. W. White, W. Krätschmer, and D. R. Huffman, "Scanning tunnelling microscopy of solid $\mathrm{C}_{60} / \mathrm{C}_{70}$," Nature, vol. 348, no. 6302, pp. 623-624, 1990.

[58] P. A. Heiney, J. E. Fischer, A. R. McGhie et al., "Orientational ordering transition in solid C60," Physical Review Letters, vol. 66, no. 22, pp. 2911-2914, 1991.
[59] K. Prassides and S. Margadonna, "Structures of Fullerenebased solids," in Fullerenes: Chemistry, Physics, and Technology, K. M. Kadish and R. S. Ruoff, Eds., p. 555, John Wiley \& Sons, 2000.

[60] H. R. Wenk and U. F. Kocks, "Representation of orientation distributions," Metallurgical transactions. A, vol. 18, no. 6, pp. 1083-1092, 1987.

[61] J. S. Kallend, U. F. Kocks, A. D. Rollett, and H. R. Wenk, “Operational texture analysis," Materials Science and Engineering A, vol. 132, no. C, pp. 1-11, 1991.

[62] X. Quelennec, Nanostructuration d'un composite Cu-Fe par déformation intense : vers un mélange à l'échelle atomique, Ph.D. thesis, University of Rouen, France, 2008.

[63] J. D. Verhoeven, W. A. Spitzig, L. L. Jones et al., "Development of deformation processed copper-refractory metal composite alloys," Journal of Materials Engineering, vol. 12, no. 2, pp. 127139, 1990.

[64] E. Snoeck, F. Lecouturier, L. Thilly et al., "Microstructural studies of in situ produced filamentary $\mathrm{Cu} / \mathrm{Nb}$ wires," Scripta Materialia, vol. 38, no. 11, pp. 1643-1648, 1998.

[65] D. Raabe and U. Hangen, "Introduction of a modified linear rule of mixtures for the modelling of the yield strength of heavily wire drawn in situ composites," Composites Science and Technology, vol. 55, no. 1, pp. 57-61, 1995.

[66] U. Hangen and D. Raabe, "Modelling of the yield strength of a heavily wire drawn $\mathrm{Cu}-20 \% \mathrm{Nb}$ composite by use of a modified linear rule of mixtures," Acta Metallurgica Et Materialia, vol. 43, no. 11, pp. 4075-4082, 1995.

[67] E. N. Popova, V. V. Popov, E. P. Romanov, N. E. Hlebova, and A. K. Shikov, "Effect of deformation and annealing on texture parameters of composite $\mathrm{Cu}-\mathrm{Nb}$ wire," Scripta Materialia, vol. 51, no. 7, pp. 727-731, 2004.

[68] J. Chen, W. Yan, W. Li, J. Miao, and X.-H. Fan, "Texture evolution and its simulation of cold drawing copper wires produced by continuous casting," Transactions of Nonferrous Metals Society of China, vol. 21, no. 1, pp. 152-158, 2011.

[69] J. Chen, W. Yan, X. Wang, and X. Fan, "Microstructure evolution of single crystal copper wires in cold drawing," Science in China, Series E: Technological Sciences, vol. 50, no. 6, pp. 736-748, 2007.

[70] J. B. Dubois, L. Thilly, P. O. Renault, F. Lecouturier, and M. Di Michiel, "Thermal stability of nanocomposite metals: in situ observation of anomalous residual stress relaxation during annealing under synchrotron radiation," Acta Materialia, vol. 58, no. 19, pp. 6504-6512, 2010.

[71] A. Kauffmann, J. Freudenberger, D. Geissler et al., "Severe deformation twinning in pure copper by cryogenic wire drawing," Acta Materialia, vol. 59, no. 20, pp. 7816-7823, 2011.

[72] S. Lefebvre, B. Devincre, and T. Hoc, "Simulation of the HallPetch effect in ultra-fine grained copper," Materials Science and Engineering A, vol. 400-401, no. 1-2, pp. 150-153, 2005.

[73] J. B. Dubois, L. Thilly, P. O. Renault, F. Lecouturier, and M. Di Michiel, "Thermal stability of nanocomposite metals: in situ observation of anomalous residual stress relaxation during annealing under synchrotron radiation," Acta Materialia, vol. 58, no. 19, pp. 6504-6512, 2010.

[74] E. O. Hall, "The deformation and ageing of mild steel: III Discussion of results," Proceedings of the Physical Society. Section $B$, vol. 64, no. 9, article no. 303, pp. 747-753, 1951.

[75] N. J. Petch, “The cleavage strength of polycrystals," Journal of the Iron and Steel Institute, vol. 74, p. 25, 1953.

[76] T. H. Courtney, Mechanical Behavior of Materials, McGrawHill, Singapore, 2000. 
[77] N. Hansen, "Hall-petch relation and boundary strengthening," Scripta Materialia, vol. 51, no. 8, pp. 801-806, 2004.

[78] N. Hansen and B. Ralph, "The strain and grain size dependence of the flow stress of copper," Acta Metallurgica, vol. 30, no. 2, pp. 411-417, 1982.

[79] A. Lasalmonie and J. L. Strudel, "Influence of grain size on the mechanical behaviour of some high strength materials," Journal of Materials Science, vol. 21, no. 6, pp. 1837-1852, 1986.

[80] S. R. Agnew and J. R. Weertman, "The influence of texture on the elastic properties of ultrafine-grain copper," Materials Science and Engineering A, vol. 242, no. 1-2, pp. 174-180, 1998.

[81] Y. K. Kwon, S. Berber, and D. Tománek, "Thermal contraction of carbon fullerenes and nanotubes," Physical Review Letters, vol. 92, no. 1, Article ID 015901, pp. 159011-159014, 2004.

[82] V. I. Zubov, N. P. Tretiakov, J. N. Teixeira Rabelo, and J. F. Sanchez Ortiz, "Calculations of the thermal expansion, cohesive energy and thermodynamic stability of a Van der Waals crystal-fullerene C $60_{0}$, Physics Letters A, vol. 194, no. 3, pp. 223-227, 1994.

[83] R. Valdiviez, D. Schrage, H. Haagenstad, and J. Szalczinger, "The thermal expansion of some common Linac materials," in Proceedings of the 21st International Linear Accelerator Conference of LINAC, TH474, Gyeongju, Republic of Korea, 2002.

[84] A. Guillet, E. Dargent, L. Delbreilh, P. Pareige, and J. M. Saiter, "Fabrication and characterization of multi-filament copper matrix-polyethylene fibres composite wire," Composites Science and Technology, vol. 69, no. 7-8, pp. 1218-1224, 2009. 

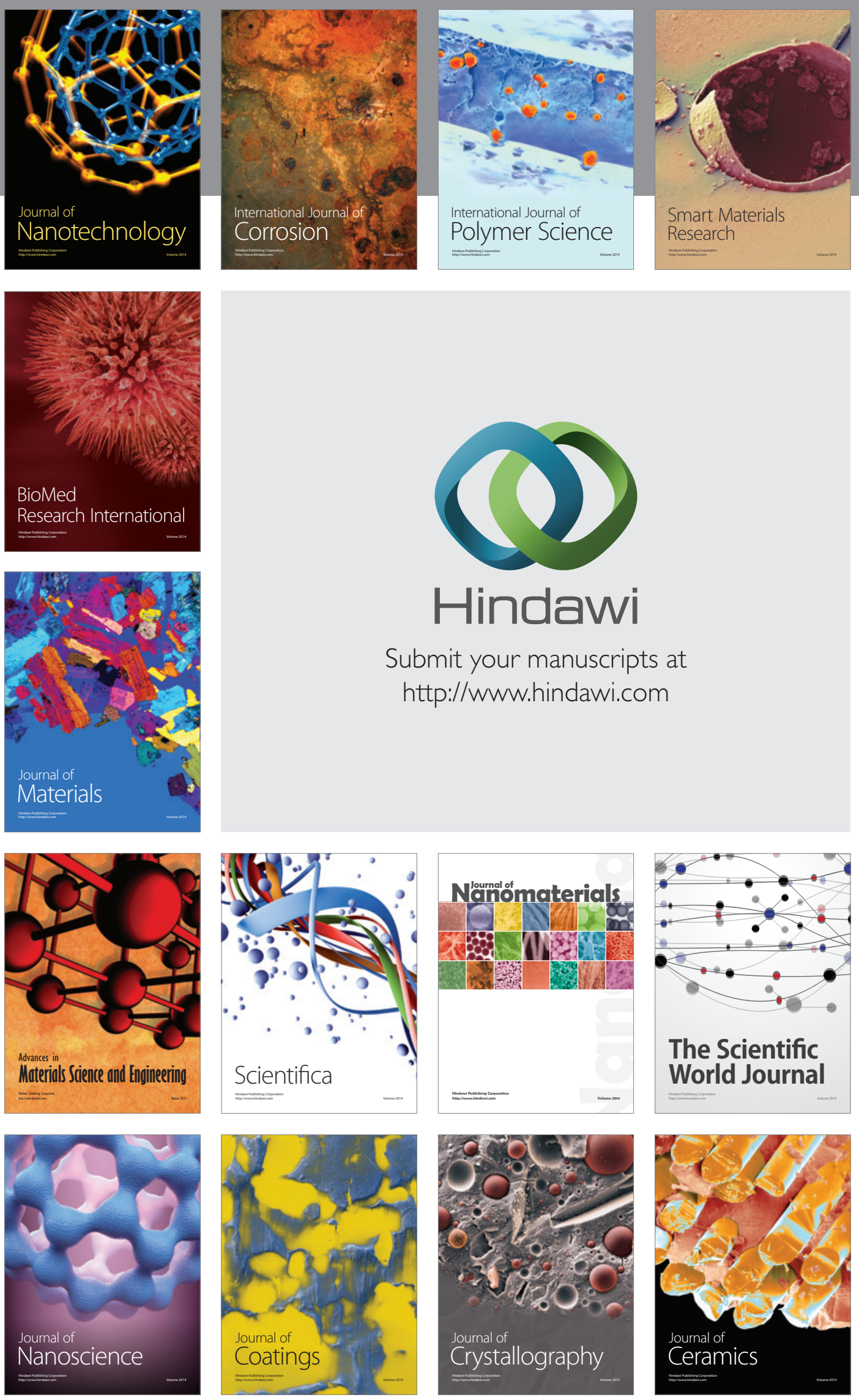

The Scientific World Journal

Submit your manuscripts at

http://www.hindawi.com

\section{World Journal}

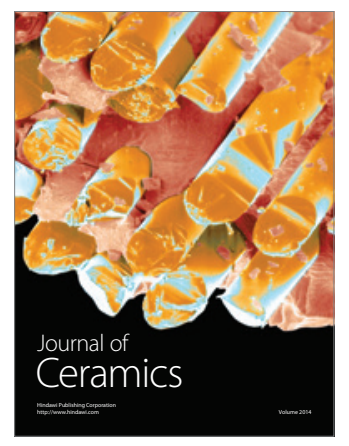

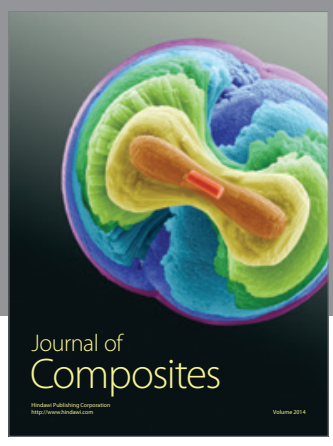
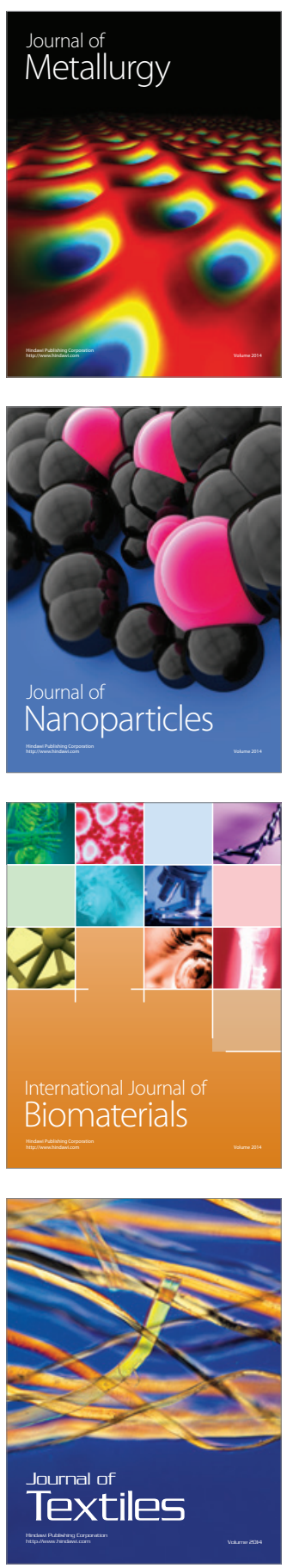